\title{
Gas exchange of Idaho fescue in response to defoliation and grazing history
}

\author{
P.S. DOESCHER, T.J. SVEJCAR, AND R.G. JAINDL
}

Authors are professor, Dept. of Rangeland Resources, Oregon State University, Corvallis, Ore. 97731; supervisory range scientist, United States Dept. of Agric.-Agric. Research Service, HC 71 4.51 Hwy 205, Bums, Ore. 97720; and Natural Resource Specialist, Oregon Dept. of Agriculture, Salem, Ore. 97310.

\begin{abstract}
We tested the hypothesis that prior grazing history would influence the defoliation responses of Idaho fescue (Festuca idahoensis) growing in a common garden environment. Plants were taken from a grazed pasture and adjacent exclosure which had not been grazed since 1937, and established in a common garden at $1 \mathrm{~m}$ spacings during spring of 1989. Plants from defoliated and nondefoliated treatments within the 2 populations were sampled during 1992 and 1993. Photosynthesis, conductance to $\mathrm{H}_{2} \mathrm{O}$, and xylem potentials were measured during the 2 growing seasons, and carbon isotope ratio $\left(\delta^{13} \mathrm{C}\right)$ was measured for senescent leaf tissue. Both within exclosure and outside exclosure defoliated plants exhibited compensatory photosynthesis that averaged a $12 \%$ increase the first year, and a $52 \%$ increase during the second year, compared with nondefoliated plants. No differences in photosynthesis occurred between the 2 collections. However, outside exclosure plants had higher stomatal conductance than did exclosure plants for the dry year 1992. Also, outside exclosure plants exhibited more negative $\delta^{13} \mathrm{C}$ (thus lower water use efficiency) than exclosure plants for 1992 and 1993 . We suggest that the higher conductance of previously-grazed plants relative to nongrazed plant populations may be an adaptive response to greater soil moisture often found in grazed sites.
\end{abstract}

Key Words: photosynthesis, water use efficiency, Festuca idahoensis

There has been a marked decline in the abundance and distribution of caespitose grasses of the shrub steppe region of western North America over the past 100 years (Mack and Thompson 1982). One of the reasons often cited for this reduction is that these grasses did not co-evolve with large populations of wild ungulates and were thus not able to tolerate high levels of livestock grazing. For example, bluebunch wheatgrass (Agropyron spicatum (Pursh) (syn. Pseudoroegneria spicata (Pursh) A. Love)) a grazing-intolerant species shows slow rates of foliar

Research was funded by the Agricultural Research Foundation, Oregon State University. The article is submitted as Oregon Agricultural Experiment Station Technical Paper No. 10730. We thank Drs. L.L. Wallace, R. Angell, and several anonymous reviewers for constructive comments on an earlier draft of this manuscript. Dr. Keith Owens provided an excellent technical review of the revised draft, and Dr. Dave Thomas provided statistical advice.

Manuscript accepted 12 Aug. 96. regrowth and allocates relatively more photosynthate to root development rather than to reestablishment of top following defoliation when compared to the grazing tolerant exotic bunchgrass, crested wheatgrass (Agropyron desertorum (Fish. ex Link) Schult.) (Caldwell et al. 1981, Richards 1984, Mueller and Richards 1986). Response shown by the high seral species Idaho fescue (Festuca idahoensis (Elmer)) indicates a higher level of grazing resistance. Jaindl et al. (1994) demonstrated that field-grown Idaho fescue exhibited high rates of foliar regrowth following defoliation. Species or ecotypes that evolved with large populations of herbivores rapidly reestablish leaf area following defoliation (McNaughton 1979, Caldwell et al. 1981, Etherington 1984, Wallace et al. 1984, Polley and Detling 1988).

This research was designed to determine if compensatory photosynthesis occurs in Idaho fescue that had been partially defoliated during the vegetative stage of growth. Compensatory photosynthesis of remaining leaves may be a mechanism that aids in reestablishment of leaf arca following defoliation (Detling et al. 1979, Wallace et al. 1984). In addition, we compared plants which have been excluded from livestock grazing since 1937 with plants from an adjacent area that have been grazed. Measurements taken included photosynthesis, stomatal conductance to $\mathrm{H}_{2} \mathrm{O}$, xylem potential, and carbon isotope ratios $\left(\delta^{13} \mathrm{C}\right)$ of leaves collected at the end of the growing season.

\section{Materials and Methods}

Idaho fescue plants were transplanted to a common garden at the Northern Great Basin Experimental Range, $64 \mathrm{~km}$ west of Burns, Oregon, USA $(1,370 \mathrm{~m}$ elevation). Soils at the common garden site were loamy alluvium weathered from rhyolite, andesite, and basalt bedrock, and are typically found on broad stream floodplains and terraces with 0-2\% slopes (Lentz and Simonson 1986). Long-term precipitation (1950-1993) averaged $283 \mathrm{~mm}$ for the crop year (September to August). Most precipitation occurs between November and May as snow and rain, and mean daily temperatures have been -0.6 and $17.6^{\circ} \mathrm{C}$ for winter and summer. Crop year precipitation for the 1992 and 1993 seasons were 245 and $523 \mathrm{~mm}$, respectively.

Twenty-five individual Idaho fescue plants were collected in May 1989 from inside and outside an exclosure in an Artemisia 
tridentata ssp wyomingensis/Festuca idahoensis plant community (Doescher et al. 1986), located within $2 \mathrm{~km}$ of the common garden site. Plants were originally collected within approximately 25 $\mathrm{m}$ of each other and transplanted $1 \mathrm{~m}$ apart in a completely randomized design. To provide uniform root competition for the border rows and to isolate the garden from the surrounding area, an additional row of Idaho fescue was established around the perimeter of the grid. Broadleaf weeds were controlled throughout the experiment using herbicides the first year of establishment, and mechanical means thereafter.

Ten plants from each collection area were selected at random and assigned to either a defoliation or no defoliation treatment (5 plants for each treatment). Approximately $60-70 \%$ of the tillers of plants in the defoliated treatment were clipped on 22 April 1992 and 19 May 1993. Defoliated plants were clipped at $5 \mathrm{~cm}$ above the ground to simulate livestock grazing, which rarely removes all tillers on the plant (Briske and Stuth 1982). Leaf photosynthesis, stomatal conductance to $\mathrm{H}_{2} \mathrm{O}$, and xylem potentials were measured for defoliated and nondefoliated plants on 24 April, 6 May, 23 June, and 6 July 1992; and on 17 June and 28 July 1993. Measurements were taken on leaves of vegetative tillers that remained undefoliated. We selected tillers that had been recruited at the onset of the growing season to ensure consistency of tiller age among treatments.

Xylem potentials, stomatal conductance to $\mathrm{H}_{2} \mathrm{O}$, and net photosynthesis were measured between 1100 and 1300 hours on each of the sampling days. Xylem potentials were determined using a Model 3005 plant water status console (Soilmoisture Equipment Corp., Santa Barbara, Calif.) for 2 or more leaves from the south side of each plant. Leaf photosynthesis and conductance were measured on 5-12 leaves per plant using an LI 6200 portable photosynthesis system (LI-COR, Inc., Lincoln, Neb.). The portion of leaves within the cuvette were excised and measured for leaf area so that photosynthesis and conductance could be expressed on a leaf area basis. We measured leaf length and diameter, and used the equation for surface of a cylinder to calculate leaf area.

Values of $\delta^{13} \mathrm{C}$ were determined on samples collected for leaf area determination during the final photosynthesis sampling of each season. Leaf material was collected from nondefoliated tillers on clipped and unclipped plants and also from regrowth on defoliated plants. Dried samples were ground and the $\delta^{13} \mathrm{C}$ values were determined with an isotope ratio mass spectrometer at the Department of Biology, Stable Isotope Lab, Boston University. Results are expressed as:

$$
\delta^{13} C(\%)=\left(\mathrm{R}_{\text {sample }} / \mathrm{R}_{\text {standard }}-1\right) * 1000 .
$$

The $\delta^{13} \mathrm{C}$ values reflect seasonal water use efficiency (Ehleringer and Osmond 1989). There is an inverse relationship between water use efficiency and discrimination against ${ }^{13} \mathrm{CO}_{2}$ (Farquhar et al. 1989). Thus, less negative values of $\delta^{13} \mathrm{C}$ indicate higher water use efficiency.

Data for net photosynthesis, conductance, and xylem water potentials were evaluated separately for each year using analysis of variance (ANOVA) for a completely randomized 3-factor (population * defoliation * time) design with repeated measures on collection and defoliation treatment in any 1 year. Individual plants served as replications. Differences in $\delta^{13} \mathrm{C}$ were evaluated using analysis of variance (ANOVA) in a completely randomized
3 factor (population * defoliation * year) design with repeated measures on collection and defoliation (Winer et al. 1991). Significant differences $(\mathrm{P}<0.05)$ among 3 or more means were separated using Waller and Duncan's BLSD mean separate procedure (Steel and Torrie 1980). Only significant differences $(\mathrm{P}<0.05)$ are reported in the text.

\section{Results}

\section{Photosynthesis}

The only significant interaction for net photosynthesis measurements was time by defoliation in 1993 (Table 1). Photosynthesis was initially higher for defoliated than nondefoliated plants during the May 1993 sampling, but declined rapidly with time (Fig. 1). Defoliated plants usually maintained higher leaf photosynthetic rates during the growing season than did nondefoliated plants (Fig. 1). Photosynthetic rates averaged 8.8 and $9.9 \mu$ mole $\mathrm{CO}_{2} \mathrm{~m}^{-2}$ $\sec ^{-1}$ (12\% increase) during the 1992 season and 6.5 and $9.9 \mu$ mole $\mathrm{m}^{-2} \mathrm{sec}^{-1}$ ( $52 \%$ increase) in the 1993 season for leaves from the nondefoliated and defoliated plants, respectively. There was no statistical difference in photosynthetic rate between plants collected inside or outside of the exclosure.

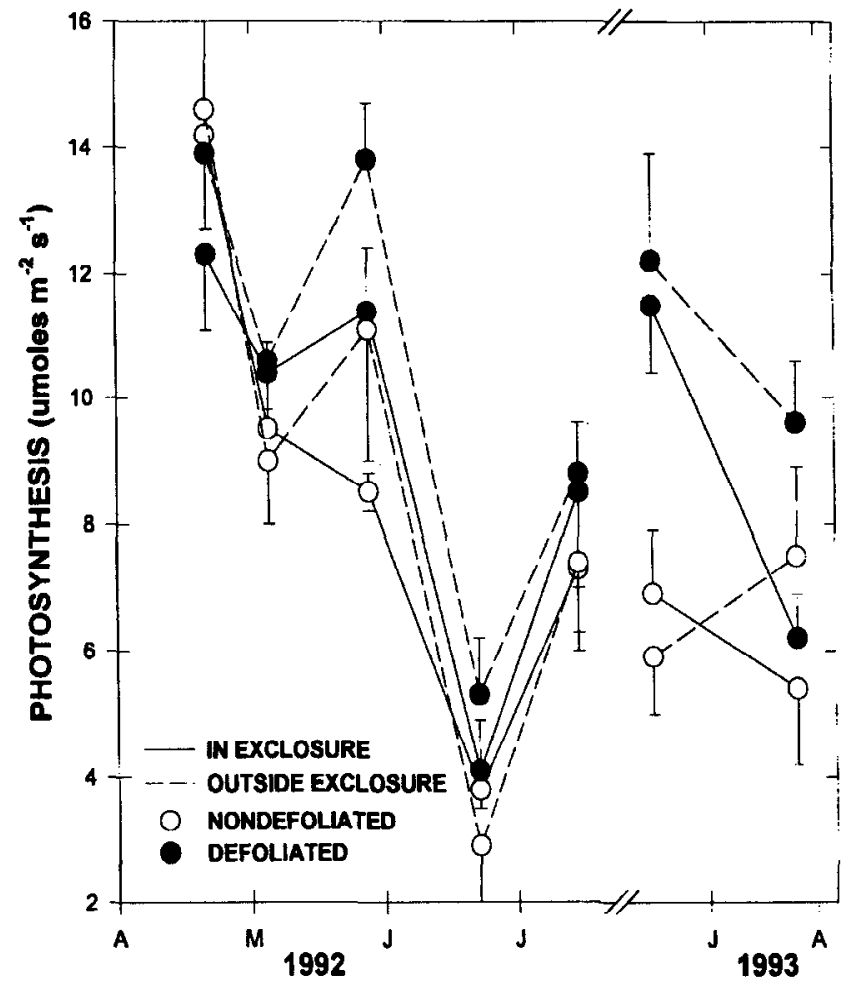

Fig. 1. Net photosynthetic rates of defoliated and nondefoliated Festuca idahoensis plants with a prior history of grazing (outside exclosure) or no grazing (in exclosure). Vertical lines are 1 standard error of the mean.

\section{Conductance}

Stomatal conductance to $\mathrm{H}_{2} \mathrm{O}$ was greater for plants from outside the exclosure as compared with plants taken inside the exclosure during 1992 (Fig. 2). Defoliated plants also had greater conductance than did nondefoliated plants. No interactions were detected 


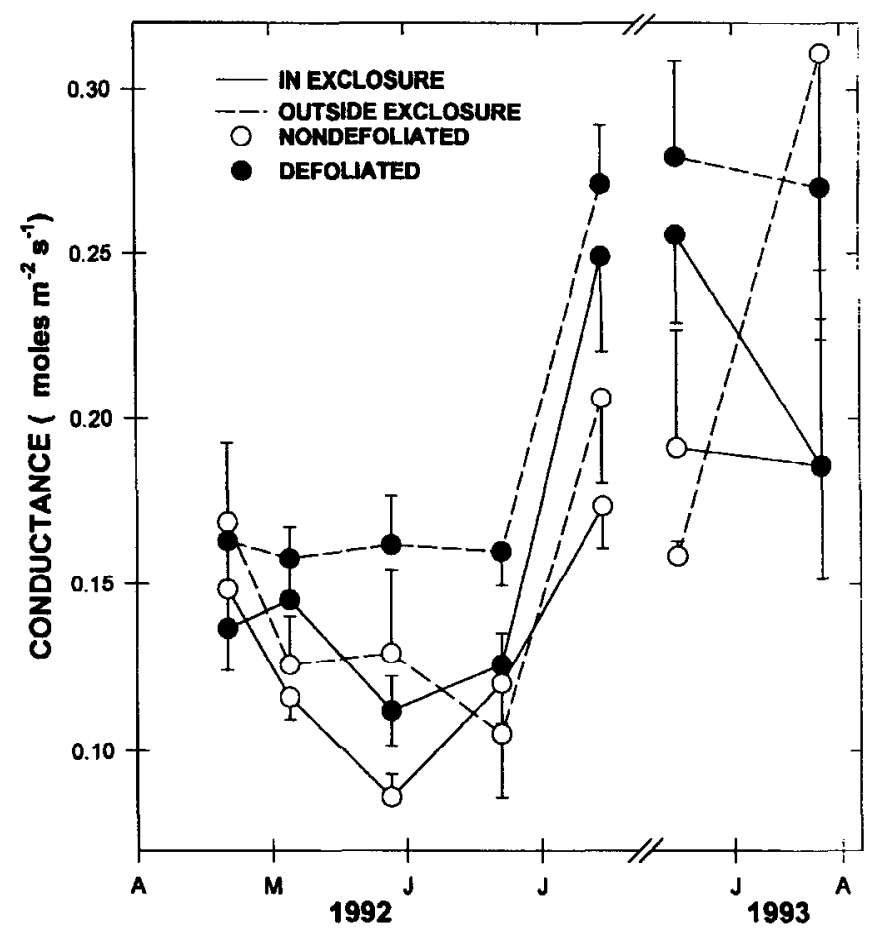

Fig. 2. Conductance of defoliated and nondefoliated Festuca idahoensis plants with a prior history of grazing (outside exclosure) or no grazing (in exclosure). Vertical lines are 1 standard error of the mean.

for stomatal conductance in 1992 (Table 1). Conductance values averaged 0.14 and $0.17 \mathrm{~mole} \mathrm{~m}^{-2} \mathrm{sec}^{-1}$ for plants from the exclosure and outside the exclosure, respectively, and 0.14 and 0.17 mole $\mathrm{m}^{-2} \mathrm{sec}^{-1}$ for nondefoliated and defoliated plants, respectively. There was a significant time by defoliation treatment interaction in 1993 (Table 1).

\section{Xylem Potentials}

Xylem water potentials varied significantly $(p<0.01)$ over time in both years (Fig. 3), but did not differ consistently between populations or defoliation treatments. Values were highest during the spring of 1992, and lowest during late June of 1992; and were less negative during June 1993 than values measured in June 1992 (but not in July).

\section{Carbon Isotope Ratios}

There was a significant year by collection interaction for $\delta^{13} \mathrm{C}$. The interaction apparently resulted from larger differences between collections in 1992 (below-average precipitation) compared to 1993 (well above-average precipitation). Defoliated plants had lower $\delta^{13} \mathrm{C}$ values than control plants in 1992, but not in 1993 (Table 2). Plants collected from inside the exclosure had less negative $\delta^{13} \mathrm{C}$ values than did those collected from outside the exclosure for both years. This indicated the exclosure plants had higher water use efficiency than did plants that had been grazed previously.

\section{Discussion}

Grasses that have coevolved with herbivory often exhibit compensatory photosynthesis of remaining leaf tissue following defoliation (Detling et al. 1979, McNaughton 1979, Painter and Detling 1981, Wallace et al. 1984). We measured compensatory photosynthesis in Idaho fescue plant populations that had been either grazed or protected from grazing since 1937 . The increase in photosynthetic rate for defoliated plants of Idaho fescue ranged from about 10 to $50 \%$. This response may help explain the high regrowth potential found in a previous study of defoliated Idaho fescue (Jaindl et al. 1994). A recent study of Idaho fescue (Merrill et al. 1994) documented overcompensation as defined by Brown and Allen (1989). Merrill et al. (1994) found that Idaho fescue plants that had been defoliated in early spring attained aboveground biomass levels that were similar to ungrazed control plants by the end of the growing season. Bluebunch wheatgrass with a similar evolutionary history to grazing as Idaho fescue, also exhibited compensatory photosynthesis (Nowak and Caldwell 1984). Rapid reestablishment of the canopy may be important for both recovery from defoliation and for competitive ability (Richards 1984). This grass is thought to have evolved under relatively light herbivore pressure (Mack and Thompson 1982). Compensatory photosynthesis following defoliation may be a common response in rangeland grasses (Senock et al. 1991), although Nowak and Caldwell (1984) questioned the importance of compensatory photosynthesis for herbivory tolerance in grasses they studied.

Table 1. Statistical analysis (ANOVA) of photosynthesis, conductance, and midday xylem potential for Idaho fescue plants for populations (grazed vs non-grazed), defoliation treatment (defoliated or not), time, and interaction effects.

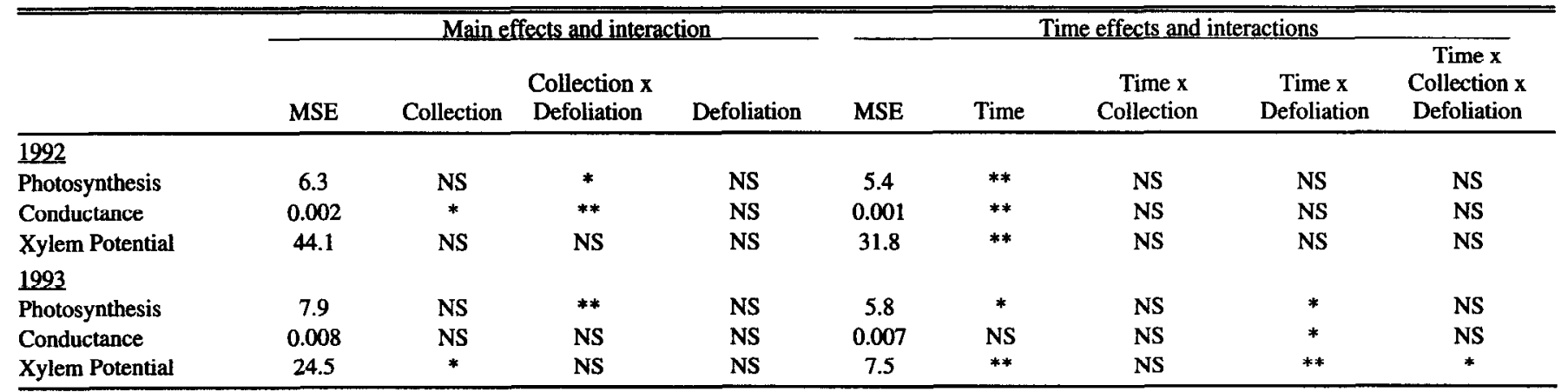

*Indicates statistical significance at $(P<0.05)$.

**Indicates statistical significance at $(P<0.01)$.

NS indicates not statistically significant $(P>0.05)$. 
Table 2. Carbon isotope ratios $\left(\delta^{13} \mathrm{C}\right)$ and standard errors (S.E.) of the means for leaves of Idaho fescue populations that were historically grazed (outside exclosure) or not grazed (exclosure) and defoliated once per year or not defoliated during the study. Precipitation was slightly below average in 1992 and nearly twice the average in 1993.

\begin{tabular}{|c|c|c|c|c|}
\hline & \multicolumn{3}{|c|}{ Defoliation Treatment } & \multirow[b]{2}{*}{ Mean } \\
\hline & $\begin{array}{c}\text { None } \\
\text { Mature Leaf }\end{array}$ & $\begin{array}{c}60-70 \% \\
\text { Mature Leaf }\end{array}$ & $\begin{array}{l}60-70 \% \\
\text { Regrowth }\end{array}$ & \\
\hline 1992 & \multicolumn{3}{|c|}{$\ldots \ldots\left(\delta^{13} \mathrm{C}\right) \ldots \ldots \ldots$} & \\
\hline Exclosure & -25.2 & -25.9 & -26.6 & $-25.9 \mathrm{a} 1$ \\
\hline Outside Exclosure & -26.3 & -26.3 & 26.6 & $26.4 \mathrm{~b}$ \\
\hline Mean & $-25.8 x$ & $-26.1 y$ & $-26.6 z$ & \\
\hline 1993 & & & & \\
\hline Exclosure & -26.0 & -26.6 & -26.3 & $-26.3 a$ \\
\hline Outside Exclosure & -26.4 & -26.4 & -26.6 & $-26.5 b$ \\
\hline Mean & -26.2 & -26.5 & -26.5 & \\
\hline
\end{tabular}

${ }^{1}$ Means within a column or row followed by different letters are significantly different within the same year $(P<0.05)$.

Defoliated plants generally exhibited higher stomatal conductance to $\mathrm{H}_{2} \mathrm{O}$ than did controls (Fig. 2), which may help explain higher photosynthetic rates for plants that had been defoliated. Wallace et al. (1984) found similar results and attributed increased photosynthetic rates following clipping to increased stomatal conductance. The higher conductances of defoliated plants may also explain their reduced water use efficiency (WUE) relative to nondefoliated control plants in 1992. Greater stomatal opening following defoliation allows for greater discrimination against ${ }^{13} \mathrm{C}$, which is inversely correlated with WUE (Farquhar et al. 1989). In a comparison of 2 cold desert bunchgrasses, Anderson and Toft (1993) found that Leymus cinereus utilized soil water to a lower level and maintained higher conductance and photosynthesis, but had reduced WUE. The situation for defoliated and nondefoliated Idaho fescue appears comparable. Defoliated plants maintained higher levels of photosynthesis and conductance, but slightly lower WUE than did nondefoliated plants. If reestablishment of a photosynthetically active canopy is a beneficial adaptive response to defoliation, then maintenance of carbon uptake and allocation of carbon to leaves may be more critical than WUE. In a competitive environment, the advantage of conserving soil water via high WUE is questionable (Jones 1980). Tilman (1988) suggested that resource consumption was the mechanism responsible for competitive displacement in cases where several species were limited by a single resource. Thus, conservation of soil water would seem to put a species at a competitive disadvantage.

It did not appear that xylem water potential was influenced by either defoliation treatment or past grazing history. Although during the wet year, outside exclosure plants had more negative xylem potential (Table 1; Fig. 3). Photosynthesis followed a similar seasonal trend to that of xylem potential, but photosynthesis is probably controlled more by soil water than by leaf water potential (Gollan et al. 1986, Davies and Zhang 1991, Tardieu et al. 1992). Defoliation may have reduced soil water extraction, but not enough to increase leaf water potential. In a native community the density of Idaho fescue plants would generally be higher than 1 plant $\mathrm{m}^{-2}$ in our spaced-plant nursery. Thus, the potential effect of defoliation on soil moisture would be greater in a natural community relative to our experimental setting. Previous studies

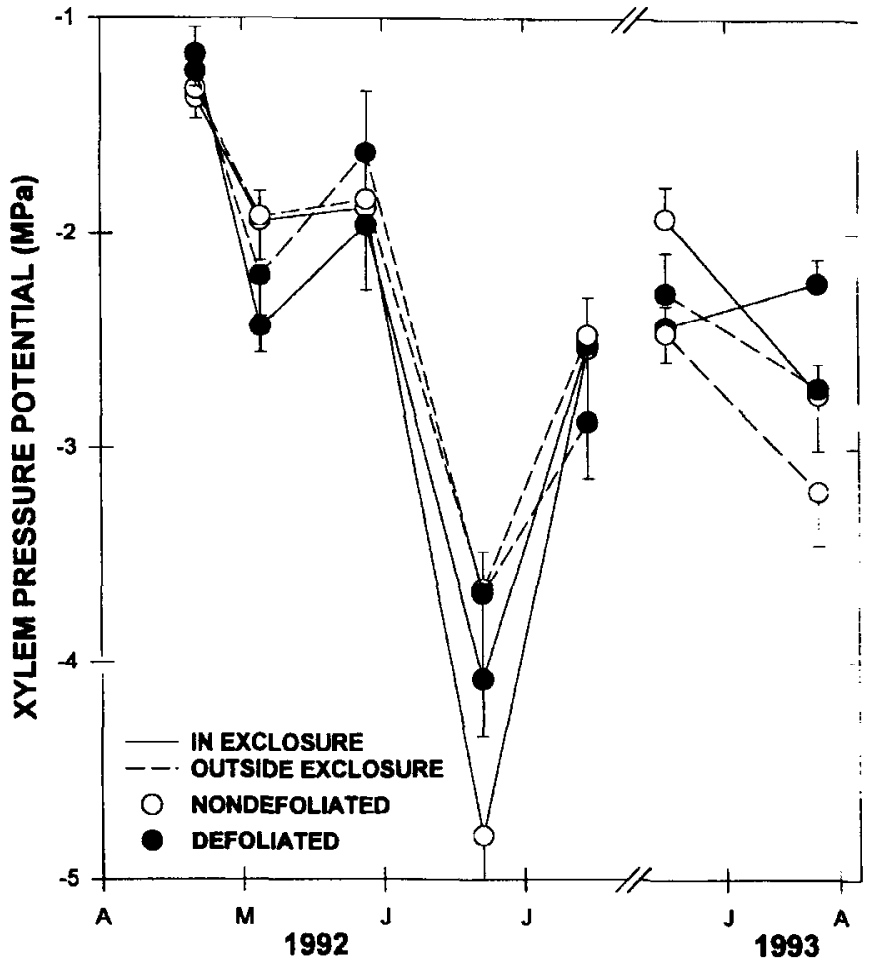

Fig. 3. Leaf xylem potential of defoliated and nondefoliated Festuca idahoensis plants with a prior history of grazing (outside exclosure) or no grazing (in exclosure). Vertical lines are 1 standard error of the mean.

have demonstrated that sufficient soil water can be conserved by reduced leaf area to increase plant water potential with heavy grazing (Svejcar and Christiansen 1987, Wraith et al. 1987).

Assuming the plants from within and outside the exclosure had a similar history of heavy grazing prior to 1937 , our research indicates that divergence in stomatal conductance has occurred between these 2 Idaho fescue populations. At least the 2 populations differed during 1992 when rainfall was slightly less than normal. The 1993 season is difficult to interpret because of the limited sampling dates and precipitation that was nearly double the long-term average. Previous work has shown morphological differences in populations with and without a long-term history of grazing (Peterson 1962, Detling and Painter 1983, Etherington 1984, Carman 1985, Butler and Briske 1988, Polley and Detling 1988, 1990, McKinney and Fowler 1991, Briske and Anderson 1992). However, little morphological change was shown for Indian ricegrass (Oryzopsis hymenoides) protected for 50 years from heavy grazing (Trlica and Oradho 1989, Orodho and Trlica 1990). Wallace et al. (1984) speculated that morphological characteristics require shorter evolutionary time periods to respond to herbivory than do physiological characteristics. Zangerl and Bazzaz (1984) found rapid short-term selection for both morphological and physiological characteristics in annual species subjected to controlled environmental gradients. Briske and Anderson (1992) measured morphological variation of Schizachyrium scoparium in response to about 25 years of livestock grazing, and we measured differences in conductance within $\mathbf{5 0}$ years. Our results may indicate relatively rapid evolutionary response in Idaho fescue in grazed environments. 


\section{Conclusion}

In conclusion, we measured compensatory photosynthesis in Idaho fescue and differences in water use efficiency and stomatal conductance between grazed and ungrazed populations. Why the outside and inside exclosure populations have diverged since 1937, and how herbivory influences the genetics of this species, are areas that require additional study.

\section{Literature Cited}

Anderson, J.E. and N.L. Toft. 1993. Depletion of soil moisture by two cold-desert bunchgrasses and effects on photosynthetic performance. Great Basin Nat. 53:97-106.

Briske, D.D. and J.W. Stuth. 1982. Tiller defoliation in a moderate and heavy grazing regime. J. Range Manage. 35:511-514.

Briske, D.D. and V.J. Anderson. 1992. Tiller dispersion in populations of the bunchgrass Schizachyrium scoparium: Implications for herbivory tolerance. Oikos 59:50-56.

Brown, B.J. and T.F.H. Allen. 1989. The importance of scale in evaluating herbivory impacts. Oikos 54:189-194.

Butler, J.L. and D.D. Briske. 1988. Population structure and tiller demography of the bunchgrass Schizachyrium scoparium in response to herbivory. Oikos 51:306-312.

Caldwell, M.M., J.H. Richards, D.A. Johnson, R.S. Nowak, and R.S. Dzurec. 1981. Coping with herbivory: Photosynthetic capacity and resource allocation in two semiarid Agropyron bunchgrasses. Oecologia 50:14-24.

Carman, J.G. 1985. Morphological characterization and defoliation responses of selected Schizachyrium scoparium genotypes. Amer. Mid. Nat. 114:37-43.

Davies, W.J. and J. Zhang. 1991. Root signals and the regulation of growth and development of plants in drying soil. Ann. Rev. Plant Physiol. Mol. Biol. 42:55-76.

Detling, J.K. and E.L. Painter. 1983. Defoliation responses of western wheatgrass populations with diverse histories of prairie dog grazing. Oecologia 57:67-71.

Detling, J.K., M.I. Dyer, and D.T. Winn. 1979. Net photosynthesis, root respiration, and regrowth of Bouteloua gracilis following simulated grazing. Oecologia 41:127-134.

Doescher, P.S., R.F Miller, S.R. Swanson, and A.H. Winward. 1986. Identification of the Artemisia tridentata ssp. Wyomingensis/Festuca idahoensis habitat type in eastern Oregon. Northwest Sci. 60:55-60.

Ehleringer, J.R. and C.B. Osmond. 1989. Stable isotopes. pp. 281-300. In: Pearcy, R.W., J. Ehleringer, H.A. Mooney, and P.W. Rundel (eds). Plant Physiological Ecology-Field Methods, and Instrumentation. Chapman Hall, London.

Etherington, J.R. 1984. Relationship between morphological adaptation to grazing, carbon balance and waterlogging tolerance in clones of Dactylis glomerata L. New Phytol. 98:647-658.

Farquhar, G.D., J.R. Ehleringer, and K.T. Hubick. 1989. Carbon isotope discrimination and photosynthesis. Ann. Rev. Plant. Physiol. Plant Mol. Biol. 40:503-37.

Gollan, T., J.B. Passioura, and R. Munns. 1986. Soil water status affects the stomatal conductance of fully turgid wheat and sunflower leaves. Aust. J. Plant Physiol. 13:459-464.

Jaindl, R.G., P.S. Doescher, R.F. Miller, and L.E. Eddleman. 1994. Persistence of Idaho fescue on degraded rangelands: Adaptation to defoliation or tolerance. J. Range Manage. 7:54-49.

Jones, H.G. 1980. Interaction and integration of adaptive responses to water stress: the implications of an unpredictable environment. pp. In: Turner, N.C. and P.J. Kramer (eds.). Adaptation of plants to water and high temperature stress. John Wiley and Sons, New York, N.Y.

Lentz, R.D. and G.H. Simonson. 1986. A detailed soils inventory and associated vegetation of Squaw Butte Range Experiment Station. Oregon State Univ. Agr. Exp. Sta. Spec. Rep. 760.184 p.

Mack, R.N. and J.N. Thompson. 1982. Evolution in steppe with few large, hooved mammals. Amer. Midl. Nat. 119:757-773.
McKinney, K.K. and N.L. Fowler. 1991. Genetic adaptations to grazing and mowing in the unpalatable grass Cenchrus incertus. Oecologia 88:238-242.

McNaughton, S.J. 1979. Grazing as an optimization process: Grass-ungulate relationships in the Serengeti. Amer. Midl. Nat. 113:691-703.

Merrill, E.H., N.L. Stanton, and J.C. Hak. 1994. Responses of bluebunch wheatgrass, Idaho fescue, and nematodes to ungulate grazing in Yellowstone National Park. Oikos 69:231-240.

Mueller, R.J. and J.H. Richards. 1986. Morpholngical analysis of tillering in Agropyron spicatum and Agropyron desertorum. Ann. Bot. 58:911-921.

Nowak, R.S. and M.M. Caldwell. 1984. A test of compensatory photosynthesis in the field: implications for herbivory tolerance. Oecologia 61:311-318.

Orodho, A.B. and M.J. Trlica. 1990. Clipping and long-term grazing effects on biomass and carbohydrate reserves of Indian ricegrass. J. Range Manage. 43:52-57.

Paintner, E.L. and J.K. Detling. 1981. Effects of defoliation on net photosynthesis and regrowth of western wheatgrass. J. Range Manage. 34:68-71.

Peterson, R.A. 1962. Factors affecting resistance of heavy grazing in needle-and-thread grass. J. Range Manage. 15:183-189.

Polley, H.W. and J.K. Detling. 1988. Herbivory tolerance of Agropyron smithii populations with different grazing histories. Oecologia 77:261-267.

Polley, H.W. and J.K. Detling. 1990. Grazing-mediated differentiation in Agropyron smithii: Evidence from populations with different grazing histories. Oikos 57:326-332.

Richards, J.H. 1984. Root growth response to defoliation in two Agropyron bunchgrasses: Field observations with an improved root periscope. Oecologia 64:21-25.

Senock, R.S., W.B. Sisson, and G.B. Donart. 1991. Compensatory photosynthesis of Sporopolus flexuosus (Thurb.) Rydb. following simulated herbivory in the northern Chihuahuan desert. Bot. Gaz. 152:275-281.

Steel, R.G.D. and J.H. Torrie. 1980. Principles and Procedures of Statistics. Ed. 2, McGraw Hill, N.Y.

Svejcar, T. and S. Christiansen. 1987. Grazing effects on water relations of caucasian bluestem. J. Range Manage. 40:15-18.

Tardieu, F., L. Bruckler, and F. LaTolie. 1992. Root clumping may affect the root water potential and the resistance to soil-root water transport. Plant and Soil 140:291-301.

Tilman, D. 1988. Plant strategies and the dynamics and structure of plant communities. Princeton University Press, Princeton, N.J.

Trlica, M.J., and A.B. Orodho. 1989. Effects of protection from grazing on morphological and chemical characteristics of Indian ricegrass (Oryzopsis hymenoides). Oikos 56:293-306.

Wallace, L.L., S.J. McNaughton, and M.B. Coughenour. 1984. Compensatory photosynthetic responses of three African graminoides to different fertilization, watering, and clipping regimes. Bot. Gaz. 15:151-156.

Winer, B.J., D.R. Brown, and K.M. Michels. 1991. Statistical principles in experimental design. McGraw Hall, N.Y.

Wraith, J.M., D.A. Johnson, R.M. Hanks, and D.V. Sisson. 1987. Soil and plant water relations in a crested wheatgrass pasture: Response to spring grazing by cattle. Oecologia 73:573-578.

Zangeri, A.R. and F.A. Bazzaz. 1984. Effects of short-ternn selection along environmental gradients on variation in populations of Amaranthus retroflexus and Abutilon theophrasti. Ecol. 65:207-217. 